\title{
PERAN INDONESIA DALAM IMPLEMENTASI ASEAN POLITICAL SECURITY COMMUNITY
}

\author{
Suwarti Sari
}

\begin{abstract}
ASEAN established on August $8^{\text {th }} 1967$ has improving its level. By signing the ASEAN Charter, ASEAN becomes an international organization. Nowadays, ASEAN makes decision on ASEAN Community. ASEAN Community has three pillars, which are ASEAN Political Security Community, ASEAN Economic Community, and ASEAN Socio-Culture Community. ASEAN Community means ASEAN as a unity, as its principle Unity in Diversity. Implementing this vision, it is not only the responsibility of ASEAN itself, but also every member nations of ASEAN have to take part to reach the goal of ASEAN Vision 2020, which accelerate to 2015. Indonesia as one of founding nations of ASEAN tries to take responsibility and participate on ASEAN goals, include implementing and reaching the ASEAN Community. ASEAN Political Security Community (APSC) aims at making ASEAN and Southeast Asia region as a stable, safe, and prosper region. Indonesia commits to take responsibility for making APSC's goals success. This research tries to analyze the role of Indonesia in making ASEAN as a stable, safe and prosper region.
\end{abstract}

Keywords: Role, ASEAN Political Security Community, ASEAN Community. 


\section{Pendahuluan}

Assocciation of Southeast Asian Nations (ASEAN) merupakan organisasi regional di Asia Tenggara yang resmi berdiri pada 8 Agustus 1967 di Bangkok, yang ditandai dengan penandatanganan Deklarasi Bangkok oleh pemimpin-pemimpin dari lima negara (founding nations), yaitu Indonesia, Thailand, Malaysia, Singapura dan Filipina. Dalam perkembangannya, saat ini negara anggota ASEAN telah berkembang menjadi sepuluh negara yaitu lima negara pendiri dan lima negara anggota lainnya yang menyusul bergabung dengan ASEAN. Kelima negara tersebut adalah Brunei Darussalam, Vietnam, Kamboja, Myanmar dan Laos.

ASEAN didirikan dengan tujuan untuk menciptakan stabilitas di Asia Tenggara. Sejak terbentuk dari tahun 1967, ASEAN akhirnya resmi menjadi organisasi internasional dengan berhasil disusunnya ASEAN Charter pada tahun 2003. Penandatanganan ASEAN Charter dilakukan pada Konferensi Tingkat Tinggi (KTT) ke-13 ASEAN di Singapura hari Selasa tanggal 20 November 2007 oleh kesepuluh pemimpin negara anggota, yaitu Sultan Hassanal Bolkiah pemimpin Brunei Darussalam, PM Hun Sen dari Kamboja, Presiden Susilo Bambang Yudhoyono Presiden Indonesia, PM Bouasone Bouphavanh berasal dari Laos, PM Abdullah Ahmad Badawi merupakan pemimpin Malaysia, PM Thein Sein mewakili Myanmar, Presiden Gloria Maccapagal Arroyo dari Filipina, PM Surayud Chulanont merupakan pemimpin Thailand, PM Nguyen Tan Dung pemimpin Vietnam dan PM Lee 
Hsien Loong dari Singapura.

Sebelumnya, pada tahun 1997 di Kuala Lumpur, ditandatangani ASEAN Vision 2020. ASEAN Vision 2020 merupakan wujud visi ASEAN untuk menjadi suatu kesatuan komunitas yang memiliki pandangan jauh ke depan, hidup di lingkungan yang damai, stabil dan makmur. ASEAN Vision inilah yang menjadi cikal bakal terbentuknya Komunitas ASEAN (ASEAN Community). Cita- cita untuk membentuk suatu Komunitas ASEAN diperkuat ketika pada KTT ke-9 ASEAN di Bali, berhasil ditandatangani Bali Concord II pada tahun 2003. Visi ASEAN untuk menjadi sebuah komunitas yang aman, stabil, damai dan makmur dipertegas dalam Bali Concord II. Selanjutnya, komitmen untuk membentuk Komunitas ASEAN dipercepat implementasinya dari yang disepakati sebelumnya pada tahun 2020 menjadi tahun 2015. Hal tesebut ditandai dengan ditandatanganinya "Cebu Declaration on the Acceleration of the Establishment of an ASEAN Community by 2015”, pada Januari 2007 di Cebu, Filipina ketika diselenggarakan KTT ke-12 ASEAN.

Komunitas ASEAN adalah sarana untuk lebih memperat integrasi ASEAN. Komunitas ASEAN dibangun melalui tiga pilar, yaitu pilar Komunitas Politik-Keamanan ASEAN yang bertujuan untuk meningkatkan kerjasama bidang politik dan keamanan demi terpeliharanya perdamaian di Asia Tenggara, serta menegakkan hak asasi manusia (HAM) dan demokrasi di Asia Tenggara. Pilar selanjutnya adalah Komunitas Ekonomi 
ASEAN (ASEAN Economic Community/MEA). MEA memiliki tujuan untuk menjadikan kawasan Asia Tenggara menjadi sebuah pasar bersama/pasar tunggal (single market) dan basis produksi.

Dengan implementasi MEA diharapkan Asia Tenggara akan menjadi kawasan yang berdaya saing dan dinamis, memiliki pembangunan yang merata dan setara serta mempercepat keterpaduan ekonomi di kawasan Asia Tenggara dan dengan kawasan di luar Asia Tenggara (ASEAN). Pilar ketiga adalah Komunitas Sosial-Budaya ASEAN. Pembentukkan komunitas ini diharapkan akan meningkatkan kesadaran, kesetiakawanan, kemitraan, dan rasa memiliki masyarakat Asia Tenggara terhadap ASEAN (Direktorat Jenderal Kerja Sama ASEAN Kementerian Luar Negeri Republik Indonesia, 2011).

Kerjasama politik dan keamanan di ASEAN, yaitu Komunitas Politik-Keamanan ASEAN (ASEAN Political Security Community/APSC) dibentuk dengan tujuan untuk mempercepat kerjasama politik dan keamanan di kawasan Asia Tenggara (ASEAN) dan mewujudkan perdamaian di antara negara-negara di kawasan Asia Tenggara. Pilar ASPC menjadi bagian yang penting sebagai instrumen untuk menciptakan perdamaian kawasan (region). APSC bergerak dalam lingkup kerjasama politik dan keamanan. Keberadaan dari Pilar ASEAN Political-Security Community menjadi bagian yang penting karena komunitas ini merupakan instrumen untuk menciptakan perdamaian kawasan. Dengan adanya 
APSC koordinasi negara anggota ASEAN diharapkan dapat tercipta dengan baik dalam menjawab tantangan global dan ancaman yang muncul di kawasan. Akan tetapi, implementasi APSC di dalam ASEAN menjadi suatu hal yang tidak mudah. APSC masih menemui kendala internal yang berkenaan dengan komitmen negara-negara anggotanya untuk mengikatkan diri kepada norma yang hendak pilar ini (APSC) ciptakan. APSC dalam pembentukannya diproyeksikan dapat mengakomodir persoalan-persoalan politik-keamanan yang muncul baik dari dalam maupun luar kawasan Asia Tenggara.

Beberapa tantangan yang harus dihadapi oleh ASEAN dalam proses mewujudkan Pilar APSC adalah persoalan di dalam tubuh ASEAN sendiri dan dari eksternal ASEAN. Koordinasi penyelesaian masalah yang melibatkan beberapa negara anggota ASEAN belum berjalan baik dan optimal, masih menyisakan ketegangan di antara negara- negara yang terlibat konflik. Faktor utama yang cukup menjadi penghambat bagi ASPC menuju komunitas keamanan di ASEAN adalah kegagalan negara anggota dalam upaya mengimplementasikan secara konsisten institusi-institusi yang telah mereka bentuk (Mohamad Rosyidin, 2013). Tantangan eksternal adalah arus globalisasi dewasa ini yang mengakibatkan dampak, tidak hanya positif tetapi juga negatif, seperti transnational crimes.

APSC didirikan dengan tujuan agar tercipta keamanan komprehensif di kawasan. Keamanan komprehesif dalam arti keamanan harus dilihat dari perspektif yang lebih luas, yaitu 
keamanan bidang politik, ekonomi dan sosial (Media Amora, 2010) Oleh sebab itu, ketiga pilar Komunitas ASEAN akan saling terkait. Persoalan yang kemudian menjadi ketertarikan peneliti adalah untuk mengkaji peran Indonesia di dalam ASPC agar ASPC dapat melaksanakan tujuan terbentuknya, yaitu menciptakan stabilitas keamanan dan politik di kawasan Asia Tenggara.

APSC berupaya membangun kawasan yang kohesif, damai dan berdaya tahan tinggi dengan tanggung jawab bersama untuk menciptakan keamanan komprehensif. Dengan cara membentuk langkah-langkah membangun kepercayaan guna mencegah konflik, membuat resolusi konflik dan penyelesaian sengketa secara damai, serta pasca konflik kemudian membangun perdamaian. Pola hubungan dan manajemen konflik yang terbentuk di dalam sebuah komunitas keamanan yakni mengedepankan multilateralisme, sebab masalah satu negara merupakan masalah bagi negara anggota lainnya juga. Akan tetapi, sense of community di dalam APSC tidak begitu terasa sebab negara anggota ASEAN lebih cenderung memilih bilateralisme dibandingkan multilateralisme dalam menyelesaikan masalah.

Selain dalam upaya manajemen konflik, APSC juga dibentuk untuk dapat mengakomodir permasalahan politik dan keamanan yang ada di kawasan. Permasalahan keamanan semakin berkembang dengan adanya perkembangan teknologi, informasi dan jalur transportasi yang semakin modern membuat ancaman keamanan di kawasan menjadi beragam. 
Kejahatan lintas batas negara merupakan salah satu ancaman. Perbedaan mekanisme penyelesaian masalah terkadang menjadi perselisihan yang tidak dapat dihindari diantara mereka. Upaya resolusi konflik yang belum sampai ke akarakarnya, negara-negara anggota ASEAN masih belum memanfaatkan instrumen yang ada secara maksimal, bahkan menyerahkan penyelesaian konflik kepada Mahkamah Internasional (Mohamad Rosyidin, 2013).

Koordinasi penyelesaian masalah yang kurang terkoordinasi yang melibatkan beberapa negara anggota juga belum berjalan baik dan menyisakan ketegangan diantara pihak yang terlibat. Situasi tersebutlah yang masih terjadi di dalam lingkup ASEAN. Faktor utama yang menghalangi jalan ASEAN menuju komunitas keamanan adalah kegagalan negara anggota dalam mengimplementasikan secara konsisten institusi-institusi yang telah mereka bentuk (Mohamad Rosyidin, 2013).

Situasi kawasan yang memiliki beragam persoalan politikkeamanan dan ancaman dari luar kawasan menjadi suatu hal yang perlu untuk dioptimalkan oleh APSC atas keberadaan dan perannya. Situasi kawasan yang berpotensi merusak hubungan antara negara-negara ASEAN diantaranya adalah Kebangkitan Tiongkok yang mendominasi dengan kapabilitas yang seimbang baik dalam hard power maupun soft power yang membuat negara yang berada di sekitarnya khawatir. Begitu halnya dengan negara di Asia Tenggara, yang menyadari bahwa kebangkitan Tiongkok tersebut bukan 
hanya bisa menjadi potensi bagi negara ASEAN untuk dapat melakukan kerjasama, akan tetapi juga menjadi ancaman apabila hubungan kerjasama dapat bergeser menjadi intervensi.

Selain kebangkitan Tiongkok, kemajuan militer India dan Korea Utara juga menjadi ancaman bagi kawasan. Dibutuhkan sikap antisipatif dan juga sarana untuk dapat menjaga keutuhan wilayah Asia Tenggara oleh negara anggota ASEAN. Kekuatan AS sebagai negara adidaya yang sudah ada, semakin menjadi kekhawatiran ketika AS lebih memfokuskan politik luar negerinya saat ini ke wilayah Asia-Pasifik. Kehadiran AS sebagai kekuatan yang dikatakan akan membangun negara di kawasan ini dan melihat bahwa terdapat potensi besar di dalam Asia Tenggara menjadi salah satu yang baik tetapi juga harus di waspadai. Kebijakan US Rebalancy yang di usung oleh AS bisa beralih menjadi strategi upaya AS mengurangi dominasi China di kawasan Asia-Pasifik. Karena AS juga turut masuk dalam konflik LCS yang terjadi dengan memberikan bantuan terhadap beberapa negara yang berselisih dengan China. Dan fokus dari US Rebalancy ini bisa menjadi hegemoni pada masa yang akan datang oleh AS di kawasan Asia Tenggara jika kapabilitas negara anggota ASEAN dan kesatuan dalam mempertahankan eksistensi negara dan kawasan Asia Tenggara itu sendiri tidak dikembangkan.

Penelitian ini akan menganalisa peran Indonesia dalam mengimplementasikan APSC dan negara-negara ASEAN 
lainnya dapat secara bersama-sama turut serta mendukung program dan kegiatan yang telah disepakati dalam APSC, sehingga perdamaian dikawasan ASEAN akan selalu terjaga.

\section{Sejarah Berdirinya ASEAN Political Security Community}

Keanggotaan ASEAN memiliki beragam konflik terutama yang berkaitan dengan kejahatan transnasional seperti pembajakan kapal laut oleh kelompok Abu Sayyaf di Filipina, human trafficking ke Eropa yang terjadi di Thailand dengan menggunakan jalur laut, penyelundupan narkotika dari Taiwan menuju Indonesia melalui Selat Malaka, dan lain sebagainya, serta konflik terorisme jatuhnya kota Marawi di Kepulauan Mindanao Filipina di tangan ISIS. Dengan adanya faktor non-politik seperti kejahatan internasional, terorisme, dan gerakan separatis bersenjata, maka situasi politik dan keamanan kawasan ASEAN sudah seharusnya mendapatkan perhatian yang lebih serius dalam perumusan integrasi kawasan ini.

ASEAN Vision 2020 pada awalnya akan dilaksanakan di tahun 2020, target tersebut dipercepat menjadi 2015 KTT ASEAN ke-12 di Cebu, Filipina tahun 2007 dan dituangkan dalam Cebu Declaration on the Accelaration of the Establishment of an ASEAN Community by 2015 (Hesty D. Lestari, 2008). Para pemimpin ASEAN menyepakati untuk melakukan percepatan ASEAN Vision menjadi tahun 2015. Fokusnya ASEAN terhadap pilar bidang ekonomi pada saat itu mempengaruhi pilar-pilar ASEAN yang lainnya termasuk pilar 
ASEAN Political Security Community (APSC). Jika dilihat kembali awal tujuan awal dibentuknya organisasi regional ASEAN untuk melakukan kerjasama dalam menjaga stabilitas keamanan kawasan tidak heran jika pilar APSC ini penting dilakukan untuk menjadi jawaban dalam tujuan awal ASEAN didirikan. APSC tersebut kemudian di ambil alih oleh para pemimpin ASEAN pada KTT ASEAN ke-14 pada tanggal 1 Maret 2009 di Cha-am, Thailand. Dalam APSC Blueprint menyebutkan ASEAN untuk menjadi komunitas aturan berbasis nilai-nilai dan norma-norma bersama secara kohesif, damai, stabil, dan tangguh dengan tanggung jawab bersama untuk keamanan yang komperhensif, serta wilayah yang dinamis dan berwawasan dunia yang terintegrasi dan saling menguntungkan. Pada tahun 2003 para pemimpin ASEAN mendirikan ASEAN Security Community (ASC) yang kemudian dirubah menjadi ASEAN Political-Security Community (APSC) sejalan dengan Piagam ASEAN yang bertujuan mempercepat kerjasama politik keamanan di ASEAN untuk mewujudkan perdamaian di kawasan, termasuk dengan masyarakat internasional.

Terbentukanya APSC tidak lepas dari instrument yang mendukungnya yang sebelumnya telah terbentuk Treaty of Amity and Cooperation in Southeast Asia (TAC) merupakan traktat yang bertujuan untuk menciptakan stabilitas politik dan keamanan di kawasan Asia Tenggara. TAC mengatur mekanisme penyelesaian konflik di antara negara-negara pihak secara damai. TAC ditandatangani pada tahun 1979 oleh 
lima kepala negara pendiri ASEAN. TAC diamandemen pada tahun 1987 untuk membuka aksesi negara-negara di kawasan lain.

Kemudian terdapat Deklarasi Kawasan Damai, Bebas, dan Netral/Zone of Peace, Freedom, and Neutrality (ZOPFAN) ditandatangani pada 27 November 1971 di Kuala Lumpur, pada pertemuan ke-5 Menteri Luar Negeri ASEAN. Deklarasi Kawasan Damai, Bebas, dan Netral (ZOPFAN) merupakan kerangka perdamaian dan kerja sama yang tidak hanya terbatas di kawasan Asia Tenggara, tetapi mencakup kawasan Asia Pasifik yang lebih luas, termasuk dengan negara-negara besar dalam bentuk tindakan menahan diri secara sukarela. ZOPFAN tidak mengesampingkan peranan negara besar di kawasan, namun memungkinkan keterlibatan negara-negara tersebut secara konstruktif dalam penanganan masalah-masalah keamanan kawasan.

Zona Bebas Senjata Nuklir Asia Tenggara/Southeast Asia Nuclear- Weapon-Free Zone (SEANWFZ) merupakan sebuah traktat yang bertujuan untuk mewujudkan kawasan Asia Tenggara yang bebas dari nuklir. Traktat itu ditandatangani pada KTT ASEAN di Bangkok, 15 Desember 1995. Penandatangan Traktat tersebut juga merupakan kontribusi terhadap upaya menuju perlucutan senjata nuklir secara menyeluruh dan mendorong perdamaian serta keamanan internasional. Selain itu, Traktat tersebut juga bertujuan untuk melindungi Kawasan Asia Tenggara dari pencemaran lingkungan dan bahaya yang disebabkan oleh sampah radio 
aktif dan bahan- bahan berbahaya lainnya.

ASEAN Political-Security Community (APSC) merupakan salah satu dari sekian banyak cara para anggota ASEAN untuk mewujudkan keamanan kawasan. Sebagai salah satu dari tiga pilar ASEAN, APSC memfokuskan pada perdamaian kawasan. Pembentukan ASEAN Political-Security Community (APSC) ditujukan untuk mempercepat kerja sama politik dan keamanan di ASEAN dalam mewujudkan perdamaian di kawasan regional dan global (Kementerian Luar Negeri Indonesia, 2015). Masyarakat Politik-Keamanan ASEAN bersifat terbuka yang didasarkan pada pendekatan keamanan yang komprehensif dan tidak ditunjukan untuk membentuk suatu pakta pertahanan/aliansi militer ataupun kebijakan luar negeri bersama. Konsep yang ditanamkan dalam APSC merefleksikan mulai berkembangnya perhatian pemimpin ASEAN pada demokrasi dan hak asasi manusia demi menciptakan kestabilan wilayah regional. Tujuan utama dari pendirian APSC adalah "Komunitas berbasis aturan dan nilai norma bersama" dengan jalan "Mempromosikan pembangunan politik berasaskan kepatuhan terhadap prinsip-prinsip demokrasi, aturan hukum, tata pemerintahan yang baik, hak asasi manusia, dan kebebasan fundamental." (Danar Widiyanta, 2010). APSC semakin menjadi perhatian khusus bagi para anggota ASEAN terutama setelah pembentukan Cetak Biru Masyarakat Politik Keamanan ASEAN. Dalam Cetak Biru Masyarakat Politik-Keamanan ASEAN yang terdiri atas tiga karakteristik utama (ASEAN Secretariat, 2009), yaitu: 
1. Masyarakat yang mengacu pada peraturan dengan kesamaan nilai dan norma (a rules based community with shared values and norms)

2. Kawasan yang kohesif, damai dan berdaya tahan tinggi dengan tanggung jawab bersama untuk menciptakan keamanan komprehensif (a cohesive, peaceful and resilient region with shared responsibility for comprehensive security)

3. Kawasan yang dinamis dan berpandangan keluar (a dynamic and outward looking region)

Dari ketiga karakteristik tersebut dapat dijabarkan, pertama "A rules-based community of shared value and norms". Dalam komunitas ASEAN mengharuskan komunitas tersebut memiliki aturan, nilai dan norma yang baik sesuai dengan negara-negara anggota ASEAN. Norma dan tata tertib yang akan menjadi tata tertib di ASEAN meliputi prinsip demokrasi, good governance dan rule of law, perlindungan HAM dan kebebasan. Untuk mencapai tujuan tersebut, ASEAN mendorong peranan masyarakat sipil tanpa membedakan jenis kelamin, ras, agama, latar belakang sosial budaya. Kedua yaitu " $A$ cohesive, peaceful, stable and resilient region with shared responsibility for comprehensive security". Fokus ASEAN dalam karakteristik yang kedua ini meliputi keamanan dalam bidang ekonomi, politik, sosial, budaya dan lingkungan.

Prinsip yang ada di ASEAN seperti ZOPFAN, TAC, 
SEANWFZ merupakan prinsip dasar bagi ASEAN dalam membangun rasa saling percaya, diplomasi preventif dan resolusi konflik mengenai masalah Asia Pasifik. Masalah keamanan non-tradisional juga menjadi perhatian dalam upaya mewujudkan keamanan, stabilitas dan ketahanan regional untuk menciptakan kawasan aman damai yang juga dpaat mengatasi berbagai konflik yang mungkin saja terjadi.

Ketiga yaitu "Dynamic and outward looking region in anincreasingly integrated and independent world". ASEAN akan selalu berusaha untuk menjalin kerjasama dengan negara di luar kawasan secara terbuka dan transparan, hal ini menjadikan ASEAN menjadi meluas dalam menjalin hubungan dengan negara lain ataupun organisasi internasional lainnya. Dengan berbagai kerjasama yang dilakukan baik secaar internal maupun eksternal akan memberikan dampak yang signifikan bagi ASEAN juga lebih dikenalnya lagi ASEAN sebagai organisasi regional yang patut diperhitungakan. Bukti nyata ASEAN melakukan kerjasama dengan negara lain yaitu adanya ASEAN+3.

Cetak Biru Komunitas Politik Keamanan ASEAN (ASEAN Political Security Community Blueprint) berpedoman pada Piagam ASEAN, prinsip-prinsip, tujuan yang terdapat didalamnya dan dibangun berdasarkan ASEAN Security Community Plan of Action, Vientiane Action Programme (VAP) (ASEAN, 2010). Cetak Biru APSC ini memiliki roadmap dan jadwal dalam pembentukan APSC pada tahun 2015, pada akhirnya dokumen tersebut diadopsi para petinggi ASEAN pada 
KTT ASEAN ke-14 pada 1 Maret 2009 di Cha-am Hua Hin, Thailand (ASEAN, 2010).

Dalam Cetak Biru APSC tujuan utama ASEAN yaitu menjawab segala bentuk ancaman, kejahatan transnasional, dan tantangan-tantangan lintas negara, dengan cara efektif. Pada bagian Cetak Biru APSC mengenai isu keamanan nontradisional diketahui berbagai aksi yang telah ditetapkan ASEAN untuk menguatkan kerjasama dalam menjawab isu-isu kejahatan non-tradisional terutama dalam kejahatan transnasional serta berbagai tantangan lintas batas negara. Salah satu aksi yang tercantum dalam Cetak Biru APSC yaitu pada bagian B.4.1 poin xvii dan xviii, yaitu :

xvii. Forge closer cooperation in fighting against sea piracy, armed robbery against ships, hijacking and smuggling, in accordance with international laws; and: xviii. Strengthen cooperation in the field of border management to jointly address matters of common concern, including forgeries of identification and travel documents, by enhancing the use of relevant technologies to effectively stem the flow of terrorists and criminals (APSC blueprint).

Secara garis besar yang tercantum dalam Cetak Biru APSC diatas yaitu mengenai peningkatan kerjasama dalam melawan pembajakan, perampokan senjata dan penyelundupan yang disesuaikan hukum internasional dan memperkuat kerjasama untuk membendung teroris dan kejahatan lain yang bersifat transnasional. Melihat kedua poin tersebut berarti peran APSC inipun sangat mempengaruhi 
keamanan dan kestabilan kawasan ASEAN. Sehingga berbagai ancaman yang tercantum dalam Cetak Biru APSC tersebut menjadi prioritas APSC dalam penanganannya.

APSC dibentuk untuk memberikan kerangka regional bagi anggotanya untuk menyelesaikan masalah-masalah keamanan dan perselisihan di dalamnya serta meningkatkan dan mempercepat kerjasama yang lebih tinggi (Zein Septian Hidayat dan Andi Widjajanto, 2013). Fungsi dari APSC di kawasan Asia Tenggara adalah untuk memberikan dorongan pada negara-negara anggota ASEAN untuk dapat mengatur sistem telah yang ada, tidak terpaku lagi pada security dilemma yang selama ini menjadi permasalahan utama di antara negara-negara anggota ASEAN, serta menekankan penyelesaian permasalahan antarnegara di kawasan melalui cara damai sebagai salah satu upaya untuk mencapai stabilitas kawasan yang selama ini dicita-citakan.

\section{Peran Indonesia dalam Implementasi ASEAN Political Security Community}

ASEAN terus mengalami perkembangan sejak pembentukan ASEAN pada 8 Agustus 1967 di Bangkok, Thailand. ASEAN berkomitmen dalam upaya memajukan kerjasama kawasan dan negara anggotanya. Menjelang abad ke-21, ASEAN menyepakati untuk membentuk kawasan yang terintegrasi. Gagasan pembentukan kawasan yang lebih terintegrasi muncul ketika pelaksanaan KTT ASEAN di Kuala Lumpur pada tahun 1997. Untuk menciptakan integrase 
kawasan, maka diusulkan membentuk suatu komunitas negara Asia Tenggara. Komunitas negara-negara Asia Tenggara tersebut bersifat terbuka, damai, stabil dan sejahtera dengan mengutamakan sikap saling peduli yang diikat dalam sebuah kemitraan yang bersifat dinamis di tahun 2020 (ASEAN Selayang Pandang, 2010). Gagasan pembentukan Komunitas ASEAN (ASEAN Community) secara resmi disepakati dengan disahkannya Bali Concord II pada KTT ASEAN ke-9 pada tahun 2003. Bali Concord II menjelasakan bahwa terdapat tiga pilar utama dalam kerjasama ASEAN Community yaitu kerjasama politik dan keamanan (ASEAN Security Community), kerjasama ekonomi (ASEAN Economic Community), dan kerjasama sosial budaya (ASEAN Socio-Cultural Community). Dokumen itu juga memperkenalkan gagasan mengenai keamanan komprehensif, dalam arti keamanan harus dilihat dari perspektif yang lebih luas yaitu keamanan politik, ekonomi dan sosial (Media Amora, 2010). Bedasarkan Deklarasi Cebu yang dihasilkan pada KTT ASEAN ke-12, pelaksanaan ASEAN Community dipercepat menjadi tahun 2015.

ASEAN Political-Security Community (APSC) merupakan salah satu dari tiga pilar yang terdapat didalam ASEAN Community, di mana APSC menjadi fokus dalam pembahasan ini. APSC merupakan pilar yang bergerak di bidang politik dan keamanan dengan tujuan mempercepat kerjasama politik dan keamanan dalam lingkup ASEAN. APSC merupakan komunitas keamanan pluralistik, karena dalam menjalankan perannya APSC tetap dilandasi oleh prinsip non-intervensi dan 
penghormatan atas kedaulatan negara lain. APSC dibentuk bukan untuk membentuk suatu pakta pertahanan (aliansi militer) ataupun kebijakan luar negeri bersama (common foreign policy) (Kementerian Luar Negeri, 2010).

Pengimplementasian APSC mengacu kepada beberapa instrumen politik dan keamanan ASEAN yang sudah ada sebelumnya. Instrumen-instrumen tersebut adalah ASEAN Charter, Zone of Peace, Freedom and Neutrality (ZOPFAN), Treaty of Amity and Cooperation in Southeast Asia (TAC), Treaty on Southeast Asia Nuclear Weapon-Free Zone (SEANWFZ), dan juga Piagam PBB serta hukum-hukum internasional lainnya yang terkait dengan cakupan APSC. APSC merupakan pelembagaan internasional dari upaya politik dan keamanan yang melibatkan seluruh anggota ASEAN dan mitra ASEAN seperti Amerika, Cina, Australia dan Jepang. APSC memiliki berbagai forum signifikan, yaitu ASEAN Intergovernmental Commission on Human Rights (AICHR), ASEAN Foreign Ministers Meeting (AMM), ASEAN Regional Forum (ARF), ASEAN Defense Minister's Meeting (ADDM), ASEAN Law Ministers Meetings (ALAWMM), dan ASEAN Ministerial Meeting on Transnasional Crimes (AMMTC).

APSC dilandasi oleh tiga karakteristik yaitu: masyarakat yang mengacu kepada peraturan dan kesamaan nilai dan norma, kawasan yang kohesif, damai dan berdaya tahan tinggi dengan tanggung jawab bersama untuk menciptakan keamanan komprehensif, serta kawasan yang dinamis dan berpandangan keluar. APSC tidak menutup diri atas dinamika dan perkembangan yang terjadi di luar kawasan. ASEAN 
bersikap dinamis terhadap berbagai perubahan dan perkembangan dunia yang semakin terintegrasi. Pembentukan APSC menjadi salah satu jawaban ASEAN untuk menyikapi perkembangan politik dan keamanan global. Seperti adanya konflik Laut China Selatan (LCS), Modernisasi Militer China, Kebijakan US Rebalancy Policy. Selain faktor eksternal, keadaan internal pada dewasa ini mengalami persoalan yang beragam. Kemajuan teknologi dan komunikasi, membuat ancaman dan tindak kejahatan semakin beragam seperti meningkatnya transnational crime seperti terrorism, money laundering, arm robbery at sea/sea piracy, arms smuggling, drugs trafficking, human trafficking, cyber crimes dan economic crimes. Perbedaan sistem politik maupun hukum juga menjadi sumber ketegangan yang dapat terjadi diantara negara anggota ASEAN.

Seiring dengan berkembangnya teknologi juga semakin meningkat pula tingkat kejahatan yang memperngaruhi stabilitas keamanan di masa yang akan datang berbagai kejahatan transnasional akan semakin meningkat begitu pula dengan berbagai ancaman yang akan hadir mempengaruhi stabilitas keamanan kawasan. Tidak hanya bagi suatu negara tetapi juga bagi suatu kawasan ASEAN yang sedang mengalami integrasi demi terstabilnya keamanan kawasan. Terbentuknya APSC telah menjadi suatu jawaban yang harus di realisasikan semaksimal mungkin untuk mencapai keamanan kawasan. Peran Indonesia dalam stabilitas keamanan akan menjadi semakin penting sebagai respon untuk perubahan-perubahan di masa yang akan datang terutama ketika stabilitas keamanan 
semakin terintegrasi. Suatu komunitas keamanan ASEAN harus mampu menyeimbangkan antara keamanan negara dan keamanan manusia.

Peran Indonesia dalam mewujudkan APSC tercantum dalam cetak biru ASEAN 2015 pada KTT ke-13 dengan tujuan untuk mempercepat kerjasama politik dan keamanan kawasan ASEAN baik bagi masyarakat anggota ASEAN. Indonesia atas nama ASEAN banyak melakukan kerjasama yang tercantum dalam cetak birunya yang kemudian dielaborasi lebih spesifik dalam bidang politik, keamanan dan hukum yang mencakup berbagai permasalahan keamanan. Dalam membangun Masyarakat Keamanan ASEAN, terdapat fondasi-fondasi konseptual yang terdiri atas tiga tataran (Hendra Maujana Saragih, 2017) yaitu: (1) Tataran pertama, terdapat kondisi-kondisi yang mempercepat terbentuknya komunitas keamanan, (2) Pada tataran kedua faktor-faktor kondusif untuk membangun rasa saling percaya dan identitas kolektif melalui interaksi langsung yang amat sering dalam berbagai pertemuan bersama, barulah terjadi pembelajaran sosial dan bangunan organisasi, (3) Pada tataran ketiga dibutuhkan sosialisasi pada tingkatan elit politik dan rakyat agar muncul rasa saling percaya yang pada gilirannya menciptakan identitas kolektif Komunitas Keamanan ASEAN ini dibentuk tidaklah dimaksudkan untuk "mengintegrasikan" politik luar negeri dan kebijakan pertahanan masing-masing negara anggota. Tantangan yang nantinya akan dihadapi perlu memiliki kekuatan dan pengetahuan yang memiliki kepentingan 
bersama serta kepentingan dari masing-masing anggota komunitas yang merupakan bagian dari proses pembelajaran dalam membangun fondasi organisasi.

Terealisasinya tiga pilar ASEAN tidak terlepas dari peran penting Indonesia dalam perkembangan ASEAN. Pembahasan yang dibahas kali ini mengenai peran Indonesia dalam implementasi APSC, sebagai bagian dari tiga pilar ASEAN. Indonesia sebagai negara berkembang saat ini tetapi juga mejadi negara terbesar di ASEAN memiliki kepentingan dalam menghadapi persepsi keamanan di Asia Tenggara dan diberikan wewenang untuk mewujudkaan APSC sebagai pilar ASEAN (Marika Moniek, 2017). Pembentukan APSC juga dibayangi kekhawatiran akan adanya campur tangan pemerintah negara besar dan hal ini menjadi suatu tantangan yang dihadapi negara anggota negara ASEAN, terutama bagi Indonesia. Sebagai penggagas dalam wacana APSC, Indonesia perlu berhati- hati dalam mengambil keputusan untuk melakukan kerjasama dengan pihak luar untuk mencapai kestabilan keamanan kawasan. Berbagai usulan Indonesia dapat diterima seperti kemajuan prinsip-prinsip demokrasi, kemajuan dan perlindungan HAM, mendorong tata kelola pemerintahan yang baik dengan memerangi korupsi, serta penanganan human trafficking yang disinergikan masing-masing anggota ASEAN.

Peran Indonesia dalam APSC menjadi salah satu bentuk diplomasi yang dilakukan Indonesia sejalan dengan kepentingan nasionalnya. Namun, tanpa tidak menghiraukan aspek-aspek negara anggota lainnya. Hanya saja peran 
Indonesia dilandaskan pada kepentingan nasionalnya. Integrasi dan demokrasi menjadi tujuan lain dalam mempertahankan stabilitas keamanan kawasan dengan terintegrasinya ASEAN, menjadikan pandangan negara lain terhadap ASEAN menjadi semakin positif. Komunitas Keamanan ASEAN menganut prinsip keamanan komprehensif yang mengakui saling keterkaitan antar aspek-aspek politik, ekonomi, dan sosial budaya. Dalam APSC terdapat mekanisme pencegahan dan penanganan konflik secara damai. Hal ini dilakukan melalui konsultasi bersama untuk membahas masalah-masalah politikkeamanan kawasan seperti keamanan maritim, perluasan kerjasama pertahanan, serta masalah-masalah keamanan nontradisional seperti, kejahatan lintas negara, kerusakan lingkungan hidup dan lain-lain. Dalam stabilitas kawasan ASEAN penting pula mengarahkan pada prinsip-prinsip nonintervensi. Banyak hal yang dilakukan Indonesia dalam pengimplementasian pilar APSC. Dalam konflik Laut Cina Selatan (LCS), Indonesia berperan aktif dalam memainkan peran meredam konflik LCS. Indonesia menyepakati dua interim measures, yaitu Joint Statement on the Application of CUES dan Hotline of Communications. Selain itu, Indonesia berperan dalam negosiasi CoC di Bali pada tahun 2017.

Selain itu, mendorong kerjasama penanggulangan terorisme, radikalisme dan violent extremism melalui implementasi ASEAN Convention on Counter Terrorism. Permasalahan Laut Cina Selatan (LCS) telah berlangsung lama semenjak sebelum terbentuknya APSC. Indonesia semakin 
gencar melakukan kerjasama keamanan atas nama ASEAN. Konflik LCS semakin menjadi permasalahan, terutama ketika banyak negara yang ikut campur dalam penyelesaian permasalahan LCS ini. Baru-baru ini ASEAN semakin memperkuat kerjasama kemaritiman yang dinyatakan dalam konferensi internasional bertajuk Resilience in the Age of Global Security di Manila, Filipina. Dalam pertemuan tersebut menurut Komando TNI Angkatan Laut (Seskoal) Laksda TNI Amarulla Octavian menyatakan, "Sejalan dengan Cetak Biru dan Program Aksi ASEAN Political-Security Community (APSC), maka konsep kerjasama keamanan kesepuluh negara anggota ASEAN meningkat dari tataran cooperative security menjadi common security," (Ulfa Arieza, 2018). Terdapat peningkatan konsep kerjasama tersebut sebagai tanda jika saat ini ASEAN lambat laun menunjukkan integrasi yang selama ini selalu digencarkan negara anggota ASEAN. Untuk memperkuat kerjasama ini menjadi salah satu cara negara anggota ASEAN untuk menghadapi berbagai tantangan dalam kemaritiman di mana wilayah maritim saat ini sebagai salah satu jalur investasi berbagai negara, salah satunya untuk meningkatkan perekonomian. Faktor kemajuan teknologi yang semakin berkembang pun menjadi salah satu alasan ASEAN memperkuat kerjasama pertahanan maritim terutama untuk pilar APSC.

Selain dengan berbagai pertemuan yang dilakukan dalam masalah keamanan maritime, ASEAN memiliki ASEAN Defense Ministers Meeting (ADMM) memiliki tujuan untuk 
meningkatkkan Confidence Building Measures (CBM) dan untuk menjaga perdamaian dan stabilitas keamanan kawasan. ADMM plus dibentuk pada tahun 2010 yang menjadi mekanisme konsultasi serta kerjasama dalam kerangka ADMM yang menunjukkan strategi outward looking ASEAN dalam hubungan eksternalnya, yaitu melibatkan negara-negara di luar ASEAN yang disebut dnegan "negara plus” (Rizky Reza Lubis, 2018). Dengan adanya ADMM plus ini menjadi langkah yang lebih maju dalam penyelesaian konflik Laut Cina Selatan karena ADMM plus ini pun terfokus pada keamanan maritim, sehingga cocok untuk melakukan dialog dan konsultasi dengan APSC.

Permasalahan hak asasi manusia menjadi permasalahan yang sangat dijunjung oleh Indonesia terutama setelah terbentuknya APSC, bahkan Indonesia menjadi pelopor untuk memasukkan hak asasi manusia dalam bagian dari APSC. Tidak heran jika Indonesia dan Filipina menjadi negara yang cukup banyak meratifikasi dan mengadopsi berbagai konvensi mengenai hak asasi manusia. Hak asasi manusia menjadi begitu penting dalam kawasan ASEAN mengingat negara anggota ASEAN belum semua merupakan negara maju dan juga memiliki sejarah panjang dalam meraih kemerdekaan, sehingga pentingnya hak asasi manusia untuk memberikan kebebasan setiap individu yang dilandaskan pada hukum yang berlaku. Dari kesepuluh anggota ASEAN Indonesia dan Filipina yang mementingkan mengenai HAM. Badan-badan ASEAN yang terkait dengan pemberantasan kejahatan lintas negara, seperti ASEAN Senior Officials on Drug Matters (ASOD), ASEAN Chiefs 
of National Police (ASEANAPOL), dan ASEAN Directors-General of Immigration and Heads of Consular Division, Ministry of Foreign Affairs Meeting (DGCIM) (Setnas ASEAN, 2015).

Pecahnya konflik di Rakhine State di tahun 2016 menjadi perhatian negara-negara di dunia tidak terkecuali negaranegara di ASEAN mengingat konflik yang terjadi masih berada di kawasan. Indonesia telah berperan secara aktif dalam upaya mengembalikan situasi yang kondusif di wilayah tersebut, baik secara bilateral maupun regional. Atas upaya diplomasi Menlu RI, Myanmar mengundang para Menteri Luar Negeri ASEAN dalam suatu forum ASEAN Foreign Ministers' Retreat di Yangon. Pada Retreat tersebut, Indonesia menyampaikan apresiasi kepada Myanmar atas inisiatif pelaksanaan Retreat tersebut, yang ditegaskan oleh Menteri Luar Negeri Republik Indonesia sebagai bentuk kedewasaan ASEAN sebagai suatu keluarga dan Masyarakat ASEAN. Indonesia berperan aktif dalam merespon perkembangan isu Rakhine State dengan mendorong dibukanya akses bantuan kemanusiaan ke Rakhine State, memberikan bantuan kemanusiaan, menawarkan berbagai inisiatif untuk membantu rekonsiliasi nasional dan interfaith dialogue, serta mendorong Myanmar memberikan update secara berkala mengenai perkembangan situasi di Rakhine. Selain menyampaikan keprihatinan atas kondisi keamanan dan kemanusiaan, Indonesia menegaskan pentingnya memberikan akses bantuan kemanusiaan yang lebih besar salah satunya melalui mekanisme yang telah ada di ASEAN. Dalam hal ini diusulkan Indonesia untuk dilakukan dengan memanfaatkan 
ASEAN Coordinating Centre for Humanitarian Assistance on Disaster Management (AHA Center) (Kementerian Luar Negeri, 2017). Namun hal tersebut terkendala oleh adanya prinsip nonintervensi yang dianut para anggota ASEAN.

Peran Indonesia dalam mewujudkan APSC tercantum dalam Cetak Biru ASEAN 2015 pada KTT ke-13 dengan tujuan untuk mempercepat kerjasama politik dan keamanan kawasan ASEAN baik bagi masyarakat anggota ASEAN. Indonesia atas nama ASEAN banyak melakukan kerjasama yang tercantum dalam cetak birunya yang kemudian dielaborasi lebih spesifik dalam bidang politik, keamanan dan hukum yang mencakup berbagai permasalahan keamanan.

Prinsip non-intervensi yang dianut oleh ASEAN juga menjadi pertimbangan dalam kerjasama APSC ini di mana dalam pengimplementasian APSC terhadap suatu permasalahan harus selalu didasarkan kepada prinsip tersebut, sehingga hambatan terbesar dalam APSC, yaitu prinsip nonintervensi yang akan mempengaruhi prospek ke depan bagi keberadaaan APSC karena dengan perbedaan kapabilitas, kemampuan, dan sumber daya di tiap negara. Apabila dalam menyelesaikan isu dalam negera sulit diselesaikan oleh negara yang bersangkutan terus dipaksakan, pencapaian stabilitas regional kawasan akan semakin sulit tercapai. Keberadaan ASEAN Political-Security Community merupakan bentuk cita-cita kestabilan, politik dan keamanan yang diharapkan dapat tercapai di kawasan Asia Tenggara. Perlunya kerjasama dengan berbagai pihak baik di kawasan Asia Tenggara maupun 
kawasan di luar Asia Tenggara dapat mempercepat tujuantujuan yang akan dicapai APSC ke depannya.

\section{Tantangan Implementasi ASEAN Political-Security Community}

ASEAN terus mengalami perkembangan sejak pembentukan ASEAN pada 8 Agustus 1967 di Bangkok, Thailand. ASEAN berkomitmen dalam upaya memajukan kerjasama kawasan dan negara anggotanya. Menjelang abad ke-21, ASEAN menyepakati untuk membentuk kawasan yang terintegrasi. Gagasan pembentukan kawasan yang lebih terintegrasi muncul ketika pelaksanaan KTT ASEAN di Kuala Lumpur pada tahun 1997. Untuk menciptakan integrasi kawasan, maka di usulkan membentuk suatu komunitas negara Asia Tenggara. Komunitas negara-negara Asia Tenggara tersebut bersifat terbuka, damai, stabil dan sejahtera dengan mengutamakan sikap saling peduli yang diikat dalam sebuah kemitraan yang bersifat dinamis di tahun 2020 (Kementerian Luar Negeri, 2017). Gagasan pembentukan komunitas ASEAN (ASEAN Community) secara resmi disepakati dengan disahkannya Bali Concord II pada KTT ASEAN ke-9 pada tahun 2003. Bali Concord II menjelasakan bahwa terdapat tiga pilar utama dalam kerjasama ASEAN Community yaitu kerjasama politik dan keamanan (ASEAN Security Community), kerjasama ekonomi (ASEAN Economic Community), dan kerjasama sosial budaya (ASEAN Socio-Cultural Community). Dokumen itu juga memperkenalkan gagasan mengenai keamanan komprehensif, 
dalam arti keamanan harus dilihat dari perspektif yang lebih luas yaitu keamanan politik, ekonomi dan sosial (Media Amora, 2010). Bedasarkan Deklarasi Cebu yang dihasilkan pada KTT ASEAN ke-12, pelaksanaan ASEAN Community dipercepat menjadi tahun 2015.

ASEAN Political-Security Community (APSC) merupakan salah satu dari tiga pilar yang terdapat didalam ASEAN Community. Dimana APSC menjadi fokus dalam pembahasan ini. APSC merupakan pilar yang bergerak dibidang politik dan keamanan dengan tujuan mempercepat kerjasama politik dan keamanan dalam lingkup ASEAN. APSC merupakan komunitas keamanan pluralistik, karena dalam menjalankan perannya APSC tetap dilandasi oleh prinsip non-intervensi dan penghormatan atas kedaulatan negara lain. APSC dibentuk bukan untuk membentuk suatu pakta pertahanan (aliansi militer) ataupun kebijakan luar negeri bersama (common foreign policy).

Pengimplementasian APSC mengacu kepada beberapa instrumen politik dan keamanan ASEAN yang sudah ada sebelumnya. Instrumen-instrumen tersebut adalah ASEAN Charter, Zone of Peace, Freedom and Neutrality (ZOPFAN), Treaty of Amity and Cooperation in Southeast Asia (TAC), Treaty on Southeast Asia Nuclear Weapon-Free Zone (SEANWFZ), dan juga Piagam PBB serta hukum-hukum internasional lainnya yang terkait dengan cakupan APSC. APSC merupakan pelembagaan internasional dari upaya politik dan keamanan yang melibatkan seluruh anggota ASEAN dan mitra ASEAN seperti Amerika, 
Cina, Australia dan Jepang. APSC memiliki berbagai forum signifikan, yaitu ASEAN Intergovernmental Commission on Human Rights (AICHR), ASEAN Foreign Ministers Meeting (AMM), ASEAN Regional Forum (ARF), ASEAN Defense Minister's Meeting (ADDM), ASEAN Law Ministers Meetings (ALAWMM), dan ASEAN Ministerial Meeting on Transnasional Crimes (AMMTC).

APSC dilandasi oleh tiga karakteristik yaitu: masyarakat yang mengacu kepada peraturan dan kesamaan nilai dan norma, kawasan yang kohesif, damai dan berdaya tahan tinggi dengan tanggung jawab bersama untuk menciptakan keamanan komprehensif, serta kawasan yang dinamis dan berpandangan keluar. APSC tidak menutup diri atas dinamika dan perkembangan yang terjadi di luar kawasan. ASEAN bersikap dinamis terhadap berbagai perubahan dan perkembangan dunia yang semakin terintegrasi. Pembentukan APSC menjadi salah satu jawaban ASEAN untuk menyikapi perkembangan politik dan keamanan global. Seperti adanya konflik Laut China Selatan (LCS), Modernisasi Militer China, Kebijakan US Rebalancy Policy. Selain faktor eksternal, keadaan internal pada dewasa ini mengalami persoalan yang beragam. Kemajuan teknologi dan komunikasi, membuat ancaman dan tindak kejahatan semakin beragam seperti meningkatnya transnational crime seperti terrorism, money laundering, arm robbery at sea/sea piracy, arms smuggling, drugs trafficking, human trafficking, cyber crimes dan economic crimes. Perbedaan sistem politik maupun hukum juga menjadi sumber ketegangan yang dapat terjadi diantara negara anggota ASEAN. 
Seiring dengan berkembangnya teknologi juga semakin meningkat pula tingkat kejahatan yang memperngaruhi stabilitas keamanan di masa yang akan datang berbagai kejahatan transnasional akan semakin meningkat begitu pula dengan berbagai ancaman yang akan hadir mempengaruhi stabilitas keamanan kawasan. Tidak hanya bagi suatu negara tetapi juga bagi suatu kawasan ASEAN yang sedang mengalami integrasi demi terstabilnya keamanan kawasan. Terbentuknya APSC telah menjadi suatu jawaban yang harus direalisasikan semaksimal mungkin untuk mencapai keamanan kawasan. Peran Indonesia dalam stabilitas keamanan akan menjadi semakin penting sebagai respon untuk perubahan- perubahan di masa yang akan datang terutama ketika stabilitas keamanan semakin terintegrasi. Suatu komunitas keamanan ASEAN harus mampu menyeimbangkan antara keamanan negara dan keamanan manusia.

Peran Indonesia dalam mewujudkan APSC tercantum dalam Cetak Biru ASEAN 2015 pada KTT ke-13 dengan tujuan untuk mempercepat kerjasama politik dan keamanan kawasan ASEAN baik bagi masyarakat anggota ASEAN. Indonesia atas nama ASEAN banyak melakukan kerjasama yang tercantum dalam cetak birunya yang kemudian dielaborasi lebih spesifik dalam bidang politik, keamanan dan hukum yang mencakup berbagai permasalahan keamanan.

Terealisasinya tiga pilar ASEAN tidak terlepas dari peran penting Indonesia dalam perkembangan ASEAN. Pembahasan dibahas kali ini mengenai peran Indonesia dalam implementasi 
APSC, sebagai bagian dari tiga pilar ASEAN. Indonesia sebagai negara berkembang saat ini tetapi juga mejadi negara terbesar di ASEAN memiliki kepentingan dalam menghadapi persepsi keamanan di Asia Tenggara dan diberikan wewenang untuk mewujudkan APSC sebagai pilar ASEAN (Marika Moniek, 2017). Dengan adanya pernyataan tersebut Indonesia pun melakukan implementasi ASEAN Political Security Community (APSC) dengan melakukan diplomasi pertahanan. Hal ini dilakukan Indonesia selain sebagai salah satu rangka dalam mempertahankan kawasan melalui APSC. Namun, dalam pengimplementasian APSC di Indonesia masih terkendala oleh sosialisasi terhadap masyarakat yang belum merata tidak dapat dipungkiri banyak masyarakat yang belum mengetahui mengenai pilar APSC ini bahkan mungkin saja banyak masyarakat yang belum mengetahui jika saat ini Indonesia telah memasuki ASEAN Community sejak tahun 2015. Pada kurun waktu tahun 2014 Ditjen Kerjasama ASEAN telah melakukan 132 kegiatan sosialisasi di 37 kabupaten/kota di seluruh Indonesia, dari 120 kegiatan yang direncanakan (Adhitya Choirul Latif. 2017). Jumlah sosialisasi yang diagendakan cenderung tidak mengalami kenaikan, namun jumlah orang dan institusi yang hadir relatif terus mengalami kenaikan, yang kemudian memberikan kesimpulanbahwa pemerintah Indonesia telah cukup aktif dalam berupaya menggalakkan Pemasyarakatan ASEAN.

Pembentukan APSC menimbulkan kekhawatiran akan adanya campur tangan pemerintah dan hal ini menjadi suatu 
tantangan yang dihadapi para anggota negara ASEAN terutama bagi Indonesia. Sebagai penggagas dalam wacana APSC, Indonesia perlu berhati-hati dalam mengambil keputusan untuk melakukan kerjasama dengan pihak luar untuk mencapai kestabilan keamanan kawasan. Berbagai usulan Indonesia dapat diterima seperti kemajuan prinsip- prinsip demokrasi, kemajuan dan perlindungan HAM, mendorong tata kelola pemerintahan yang baik dengan memerangi korupsi, serta penanganan human trafficking yang disinergikan masingmasing anggota ASEAN.

Peran Indonesia dalam APSC menjadi salah satu bentuk diplomasi yang dilakukan Indonesia sejalan dengan kepentingan nasionalnya. Namun, tanpa tidak menghiraukan aspek-aspek negara anggota lainnya. Hanya saja peran Indonesia dilandaskan pada kepentingan nasionalnya. Integrasi dan demokrasi menjadi tujuan lain dalam mempertahankan stabilitas keamanan kawasan dengan terintegrasinya ASEAN, menjadikan pandangan negara lain terhadap ASEAN menjadi semakin positif. Komunitas Keamanan ASEAN menganut prinsip keamanan komprehensif yang mengakui saling keterkaitan antar aspek-aspek politik, ekonomi, dan sosial budaya. Dalam APSC terdapat mekanisme pencegahan dan penanganan konflik secara damai. Hal ini dilakukan melalui konsultasi bersama untuk membahas masalah-masalah politikkeamanan kawasan seperti keamanan maritim, perluasan kerjasama pertahanan, serta masalah-masalah keamanan nontradisional seperti, kejahatan lintas negara, kerusakan 
lingkungan hidup dan lain-lain. Dalam stabilitas kawasan ASEAN penting pula mengarahkan pada prinsip-prinsip nonintervensi.

Banyak hal yang dilakukan Indonesia dalam pengimplementasian pilar APSC, dalam konflik Laut Cina Selatan (LCS), Indonesia menjadi berperan aktif dalam memainkan peran konflik LCS. Indonesia menyepakati dua interim measures, yaitu Joint Statement on the Application of CUES dan Hotline of Communications. Selain itu, Indonesia berperan dalam negosiasi CoC di Bali pada tahun 2017. Mendorong kerjasama penanggulangan terorisme, radikalisme dan violent extremism melalui implementasi ASEAN Convention on Counter Terrorism. Permasalahan Laut Cina Selatan (LCS) telah berlangsung lama semenjak terbentuknya APSC, Indonesia semakin gencar melakukan kerjasama keamanan atas nama ASEAN. Konflik LCS semakin menjadi permasalahan, terutama ketika banyak negara yang ikut campur dalam penyelesaian permasalahan LCS ini. Baru-baru ini ASEAN semakin memperkuat kerjasama kemaritiman yang dinyatakan dalam konferensi internasional bertajuk Resilience in the Age of Global Security di Manila, Filipina. Dalam pertemuan tersebut menurut Komando TNI Angkatan Laut (Seskoal) Laksda TNI Amarulla Octavian menyatakan, "Sejalan dengan C etak Biru dan Program Aksi ASEAN Political-Security Community (APSC), maka konsep kerjasama keamanan kesepuluh negara anggota ASEAN meningkat dari tataran cooperative security menjadi common security," (Ulfa Arieza, 
2018). Terdapat peningkatan konsep kerjasama tersebut sebagai tanda jika saat ini ASEAN lambat-laun menunjukkan intergrasi yang selama ini selalu digencarkan para anggota ASEAN.

Selain dengan berbagai pertemuan yang dilakukan dalam masalah keamanan maritim ASEAN memiliki ASEAN Defense Ministers Meeting (ADMM) memiliki tujuan untuk meningkatkkan Confidence Building Measures (CBM) dan untuk menjaga perdamaian dan stabilitas keamanan kawasan. ADMM plus dibentuk pada tahun 2010 yang menjadi mekanisme konsultasi serta kerjasama dalam kerangka ADMM yang menunjukkan strategi outward looking ASEAN dalam hubungan eksternalnya, yaitu melibatkan negara-negara di luar ASEAN yang disebut dnegan "negara plus" (Rizky Reza Lubis, 2018). Dengan adanya ADMM plus ini menjadi langkah yang lebih maju dalam penyelesaian konflik Laut Cina Selatan karena ADMM plus ini pun terfokus pada keamanan maritim, sehingga cocok untuk melakukan dialog dan konsultasi dengan APSC.

Upaya perlindungan hak asasi manusia menjadi sebuah tantangan bagi ASEAN dan juga pilar APSC. Pada awalnya APSC cenderung hanya terfokus pada sosialisasi dan edukasi pentingnya perlindungan hak asasi manusia, tidak ada tindakan untuk mengatasi perlindungan hak asasi manusia. Namun semua itu memiliki alasan, yaitu prinsip non-intervensi yang telah menjadi prinsip para anggota ASEAN sehingga dalam menjalankan tugas dan fungsi APSC agak terhambat. 
Seiring dengan berjalannya waktu Indonesia menjadi salah satu negara anggota ASEAN yang berani memberikan pendapat mengenai pentingnya perlindungan hak asasi manusia karena ini menyangkut keamanan manusia juga menjadi bagian APSC.

Kerjasama dalam memberantas penyeludupan dan perdagangan orang didasari dari konvensi ASEAN Convention Againts Trafficking in Person, Especially Women and Children. Dalam pemberatasan perdagangan dan penyelundupan manusia ternyata di wilayah Asia Tenggara masalah tersebut semakin merajalela. Menurut Trafficking in Person (TIP), perdagangan manusia dapat dilihat dari standar minimum untuk penghapusan perdagangan sesuai dengan undangundang Trafficking Victims Protection Act (TVPA) berdasarkan Departemen Luar Negeri Amerika Serikat tahun 2000. Terdapat tiga tingkatan yang membahas mengenai penghapusan perdagangan manusia. Tingkat pertama, pemerintah telah mengakui dan mematuhi standar yang telah ditetapkan oleh TVPA. Tingkat kedua, pemerintah tidak sepenuhnya mematuhi standar yang ditetapkan, tetapi beusaha secara signifikan untuk memenuhi standar. Tingkat ketiga, pemerintah tidak mematuhi standar TVPA dan tidak berupaya untuk memenuhi standar TVPA yang telah ada.

Pemberantasan korupsi menjadi salah satu fokus APSC, tingkat korupsi yang semakin tinggi sehingga tidak heran pemberantasan korupsi digencarkan dengan melakukan berbagai kerjasama dan proram-program pemberantasan 
korupsi. Salah satu Negara anggota yang memiliki tingkat korupsi tinggi adalah Indonesia yang dapat mneyebabkan ketidakstabilan bagi sistem pemerintahan. Saat ini korupsi tidak hanya berada dalam wilayah internal saja namun juga telah melibatkan pihak eksternal yang saat ini mulai bermunculan menjadikan korupsi ini menjadi korupsi tingkat internasional. Di Indonesia sendiri telah memiliki badan dalam pemberantasan korupsi seperti Komisi Pemberantasan Korupsi (KPK), Pengadilan Tindak Pidana Korupsi, dan Kepolisian Republik Indonesia. Indonesia pun telah melakukan kerjasama dengan aktor-aktor internasional dalam pemberantasan korupsi. Namun dalam pengimplementasian APSC semua Negara anggota ASEAN harus lebih memfokuskan terhadap tujuan-tujuan dari APSC tersebut.

Menteri Koordinator Bidang Politik, Hukum dan Keamanan Wiranto sebagai perwakilan dalam pertemuan APSC ke-18 di Singapura. Dalam pertemuan tersebut Wiranto menyarankan tiga hal yang berkaitan dengan APSC. Pertama, mengenai konflik di Myanmar, Wiranto menyarankan agar negara anggota ASEAN untuk mengambil alih kasus tersebut supaya menemukan titik terang penyelesaian di Myanmar. Kedua, pembahasan mengenai cyber secuity yang menjadi tantangan setiap negara karena semakin terbuka akses informasi dari berbagai negara. Ketiga mengenai our eyes merupakan bentuk sharing individasi dan sharing intelijen untuk kepentingan pertahanan termasuk terorisme (Muhamad Agil Aliansyah, 2018). Terorisme menjadi 
kejahatan transnasional yang paling mencuri perhatian dari berbagai pihak terutama organisasi seperti ASEAN yang memiliki tujuan menjaga stabilitas keamanan kawasan. Semenjak pilar APSC terbentuk, ASEAN melalui pilar ini semakin menggencarkan kerjasama terutama dalam isu terorisme. Peran Indonesia dalam mewujudkan APSC tercantum dalam Cetak Biru ASEAN 2015 pada KTT ke-13 dengan tujuan untuk mempercepat kerjasama politik dan keamanan kawasan ASEAN baik bagi masyarakat anggota ASEAN. Indonesia atas nama ASEAN banyak melakukan kerjasama yang tercantum dalam cetak birunya yang kemudian dielaborasi lebih spesifik dalam bidang politik, keamanan dan hukum yang mencakup berbagai permasalahan keamanan.

Prinsip non-intervensi yang dianut oleh ASEAN juga menjadi pertimbangan dalam kerjasama APSC ini di mana dalam pengimplementasian APSC terhadap suatu permasalahan harus selalu didasarkan kepada prinsip tersebut, sehingga hambatan terbesar dalam APSC, yaitu prinsip non-intervensi yang akan mempengaruhi prospek ke depan bagi keberadaaan APSC karena dengan perbedaan kapabilitas, kemampuan, dan sumber daya di tiap negara. Apabila dalam menyelesaikan isu dalam negeri sulit diselesaikan oleh negara yang bersangkutan terus dipaksakan, pencapaian stabilitas regional kawasan akan semakin sulit tercapai. Keberadaan ASEAN Political-Security Community merupakan bentuk cita-cita kestabilan, politik dan keamanan 
yang diharapkan dapat tercapai di kawasan Asia Tenggara. Perlunya kerjasama dengan berbagai pihak baik di kawasan Asia Tenggara maupun kawasan di luar Asia Tenggara dapat mempercepat tujuan-tujuan yang akan dicapai APSC ke depannya. 


\section{DAFTAR PUSTAKA}

Buku

Acharya, Amitav. Constructing A Security Community in Southeast Asia: ASEAN and The Problem of Regional Order. London: Routledge, 2001.

Anthony, Mely Caballero. Regional Security in Southeast Asia: Beyond the ASEAN Way. Singapore: ISEAS Publication, 2005.

ASEAN. The ASEAN Charter. Jakarta: ASEAN Secretariat, 2008. . ASEAN Political-Security Community Blueprint. Jakarta: ASEAN Secretariat, 2009.

. ASEAN Political-Security Community Blueprint 2025. Jakarta: ASEAN Secretariat, 2016.

Bakry, Umar Suryadi. Metode Penelitian Hubungan Internasional. Yogyakarta: Pustaka Pelajar, 2016.

Basrowi dan Suwandi. Memahami Penelitian Kualitatif. Jakarta: Rineka Cipta, 2008.

Bannet, Alvin LeRoy Bannet dan James K. Oliver. International Organization: Principles and Issues. New Jersey: Prentice Hall, 2002.

Burchill, Scott dan Andrew Linklater. Teori-Teori Hubungan Internasional. Terj. M. Sobirin. Bandung: Nusa Media, 2015.

Buzan, Barry dan Ole Waefer. Regions and Power: The Structure of International Security. Cambridge: Cambridge University Press, 2003.

Church, Peter A. Short History of South-East Asia. New Jersey : Wiley, 2009.

Cipto, Bambang. Hubungan Internasional Di Asia Tenggara: Teropong Terhadap Dinamika, Realitas, dan Masa Depan. Yogyakarta: Pustaka Pelajar, 2007.

Creswell, Jhon W. Pendekatan Metode Kualitatif, Kuantitatif, dan 
Campuran. Edisi Keempat. Terj. Achmad Fawaid dan Rianayati Kusmini Pancasari. Yogyakarta: Pustaka Pelajar, 2016.

Direktorat Jendral Kerjasama ASEAN. ASEAN Selayang Pandang. Edisi Ke-19. Jakarta: Direktorat Jenderal Kerjasama ASEAN, 2010.

Finnemore, Martha. National Interest in International Society. Ithaca: Cornell Universit Press, 1996.

Hayati, Sri dan Ahmad Yani. Geografi Politik. Bandung: PT. Refika Aditama, 2011.

Jackson, Robert dan Georg Sorensen. Pengantar Studi Hubungan Internasional. Terj. Dadan Suryadipura. Yogyakarta: Pustaka Pelajar, 2009.

. Pengantar Studi Hubungan Internasional. Edisi ke 5. Terj. Dadan Suryadipura dan Pancasari Suryatiman. Yogyakarta: Pustaka Pelajar, 2016.

Karns, Margaret P dan Karen A. Mingst. International Organizations: The Politics and Processes of Global Governance. Colorado: Lynne Rienner Publishers, 2004.

Katzenstein, Peter. Rethingking Japanese Security: Internal and External Dimensions. London: Routledge, 2008.

Lake, David A. dan Patrick M. Morgan. Regional Organs: Building Security in a New World. Pennsylvania: Pennsylvannia State University Press, 1997.

Landman, Todd. Issue and Methods in Comparative Politics: An Introduction. New York: Routledge, 2003.

Lau, Albert. Southeast Asia and The Cold War. London: Routledge, 2012.

Layder, Derek. Understanding Social Theory 2nd edition. London: SAGE Publicaction, 2006.

Luhulima. Dinamika Asia Tenggara Menuju 2015. Yogyakarta: Pustaka Pelajar dan P2P LIPI, 2011. 
Luhulima, C.P.F., dkk. Dimensi Kerangka Kegiatan dalam Kerja Sama ASEAN. Jakarta: Seknas ASEAN Deplu RI, 1986.

Mas'oed, Mohtar. Ilmu Hubungan Internasional: Disiplin dan Metodologi. Jakarta: LP3ES, 1995.

Miles, Matthew B. dan Huberman, A. Michael. Qualitative Data Analysis Second Edition. California: SAGE Publication, 1994.

Nuraeni S, at al., Regionalisme Dalam Studi Hubungan Internasional. Yogyakarta: Pustaka Pelajar, 2010.

Octavian, Amarulla. Militer dan Globalisasi: Studi Soiologi Militer dalam Konteks Globalisasi dan Kontribusinya bagi Transformasi TNI. Jakarta: UI Press, 2012.

Rosyidin, Mohamad. The Power of Ideas: Konstruktivisme dalam Studi Hubungan Internasional. Yogyakarta: Tiara Wacana, 2015.

Rudy, T. May. Adminitrasi dan Organisasi Internasional. Bandung: Refika Aditama, 2009.

Ruggie, John Gerard. Constructing The World Polity: Essays on International Institutionalization. New York: Routledge, 1998. Sugiyono. Memahami Penelitian Kualitatif. Bandung: Alfabeta, 2007.

. Metode Penelitian Kuantitatif, Kualitatif, dan R\&D. Bandung: Alfabeta, 2015.

Weatherbee, Donald E. International Relations in Southeast Asia. Lanham: Rowman \& Littlefield Publisher Inc., 2005.

Wendt, Alexander. Social Theory of International Politics. Cambridge: Cambridge University Press, 1999.

Jurnal

Buzan, Barry. "The Southeast Asian Security Complex." Contemporary Southeast Asia. Vol. 10 No. 1. (1998).

Direktorat Jenderal Kerjasama ASEAN. "Perdamaian dan Stabilitas Keamanan: 'Conditio Sine Qua Non' bagi Masyarakat ASEAN". Masyarakat ASEAN Edisi 10/ Desember. 2015: 6-8.

Emmerson, Donald K. "Security, Community, and Democracy in 
Southeast Asia: Analyzing ASEAN." Japanese Journal of Political Science. Vol. 6 No. 2 (2005) 165-185.

Finnemore, Martha dan Sikkink, Kathryn. "Taking Stock: The Constructivist Research Program in International Relations and Comparative Politics," Annual Review of Political Science. Vol. 4 (2001).

Goh, Evelyn. "Great Powers and Hierarchical Order in Southeast Asia: Analyzing Regional Security Strategies". International Security. Vol. 32 No. 3 (2007) 113-157.

Hirschman, Charles dan Bonaparte, Sabrina. "Population and Society in Southeast Asia : A Historical Perspective." Journal of Southeast Asian Studies. Vol. 25 No. 2. (1994) 381-416.

I Nyoman Sudira, "Konflik Laut Cina Selatan dan Politik Luar Negeri Indonesia ke Amerika dan Eropa." Jurnal Universitas Katolik Parahyangan. (2015) 143-161.

Kardiyat Wiharyanto. "Proses Berdirinya ASEAN," Jurnal Historia Vitae. Vol. 24 No. 2 (2010).

Lisbet "Peningkatan Kekuatan Militer China." Pusat Pengkajian Pengolahan Data dan Informasi Setjen DPR RI. Vol. IV, No. 05 (2012) 1-8.

Mohamad Rosyidin. "Membangun Komunitas yang Kredibel: Komitmen terhadap Institusi sebagai Prasyarat Menuju Komunitas Keamanan ASEAN 2015." Jurnal Universitas Paramadina. Vol. 10 No. 3. (2013) 876-892.

Moniek, Marika. "Peran Komunitass Epistemik dalam Diplomasi Pertahanan Indonesia melalui Kerangka APSC". Jurnal Prodi Diplomasi Pertahanan Volume 3 Nomor 2. (2017).

Najamuddin Khairur Rijal. "Tinjauan Konstruktivisme Politik-Hukum Internasional dalam Pertimbangan Indonesia pada Pembentukan Asean Political-Security Community." Opinio Juris. Vol. 19. (2016) 31-46.

Rober S. Ross, "Balance of power politics and the rise of China: accomondation and balancing in East Asia." Security Studies. 15. (2006) 355-395. 
Saragih, Hendra Maujana. "Kebijakan Pembentukan Komunitas Asean 2015: Tantangan Dan Harapan Dalam Penciptaan Stabilitas Kawasan". Jurnal Administrative Reform, Vol. 5, No. 4, Desember 2017. (2017).

Wendt, Alexander. "Constructing International Politics." International Security. Vol. 20 No. 01 (1995) 71-81.

Majalah

Direktorat Jenderal Kerjasama ASEAN. "Perdamaian dan Stabilitas Keamanan: 'Conditio Sine Qua Non' bagi Masyarakat ASEAN". Masyarakat ASEAN. Edisi 10. Desember. 2015: 6-8.

Skripsi/Tesis/Disertasi

Aldrin Erwinsyah. "Pengaruh Modernisasi Militer China Terhadap Kebijakan Amerika Serikat di Asia Pasifik.” Tesis., Universitas Indonesia, 2011.

Lesly Gijsbert Christian Hosang. "Pandangan Paradigma Realisme, Liberalisme, dan Konstruktivisme terhadap ASEAN Political Security Community 2015 sebagai Kerjasama Keamanan di Kawasan Asia Tenggara." Skripsi., Universitas Indonesia, 2012.

Media Amora. "Arti Strategis Piagam ASEAN (ASEAN Charter) Terhadap Kerjasama Regional ASEAN." Tesis., Universitas Indonesia, 2010.

Internet

Adhitya Choirul Latif, Jurnal HI UNS, internet (28 Desember 2016), diakses pada 10 Januari 2018, Pkl. 21.00 WIB, https://jurnalhiuns.files.wordpress.com.

ASEAN. "The Asean Declaration (Bangkok Declaration) Bangkok, 8 August 1967". ASEAN. (27 Januari 2016) internet. 15 Desember 2016. http://asean.org/the-aseandeclaration- bangkok-declaration-bangkok-8-august-1967/

. "Treaty of Amity and Cooperation in Southeast Asia Indonesia, 24 February 1976". ASEAN. (27 Januari 2016) internet. 11 Januari 2017. http://asean.org/treaty-amitycooperation-southeast-asia-indonesia-24-february-1976/. 
http://www.bbc.com/indonesia/laporan_khusus/2011/07/110719_ spratlyconflict, diunduh pada hari Kamis, 18 Februari 2016, pukul 21.54

Direktorat Kerjasama ASEAN. "Masyarakat Politik-Keamanan ASEAN", Kementerian Luar Negeri Indonesia. (17 Maret 2015) internet. $11 \quad$ November 2016 http://www.kemlu.go.id/id/kebijakan/asean/Pages/Masyarak at-Politik-Keamanan-ASEAN.aspx "Sejarah dan Latar Belakang Pembentukan ASEAN".

Kementerian Luar Negeri Republik Indonesia. (17 Maret 2015) internet. $7 \quad$ Januari 2017. http://www.kemlu.go.id/id/kebijakan/asean/Pages/Sejarahdan-Latar-Pembentukan-ASEAN.aspx

. "Hasil Pertemuan ke-6 Dewan Komunitas Politik-Keamanan ASEAN, Bali, Indonesia, 16 November 2011". (16 November 2011) internet. 5 Februari 2017. http://www.kemlu.go.id/id/berita/siaran-pers/Pages/HasilPertemuan-ke-6-Dewan-Komunitas-Politik-Keamanan-ASEANBali-Indonesia-16-November-2011.aspx

Kementerian Luar Negeri Republik Indonesia. "Piagam ASEAN".

Kementerian Luar Negeri Republik Indonesia. (5 September 2009) internet. $11 \quad$ Januari 2017. http://www.kemlu.go.id/id/kebijakan/asean/Pages/PiagamASEAN.aspx.

Muhamad Agil Aliansyah, RI Dorong Penguatan Keamanan Siber \& Kerjasama Intelijen Antisipasi Terorisme. Internet. 20 Desember 2018. http://m.merdeka.com/amp/peristiwa/ri-dorongpenguatan-keamanan-siber-kerjasama-intelijen- antisipasiterorisme.html

Setnas ASEAN, ASEAN Ministerial Meeting on Transnasional Crime. Internet. 20 Desember 2018. http//setnas-asean.id/aseanministerial-meeting-on-transnasional-crime-ammtc. 